\title{
NARRATING A FRAGMENTED NATION: ARUNDHATI ROY'S MINISTRY OF UTMOST HAPPINESS
}

\author{
Nalini Iyer \\ Seattle University, USA
}

\begin{abstract}
Published nearly 20 years after the award- winning debut novel, God of Small Things, Roy's Ministry of Utmost Happiness seeks to articulate a postcolonial nation's history from the perspective of the marginalized. Anjum, a hijra, Saddam Hussain, a Dalit, and Tilottama, a maverick young woman are among the main characters in this sprawling narrative whose tales intertwine to capture the failure of the secular democratic nation state. Although Anjum's family history begins with the Partition and its impact on the Muslims in Delhi, the prime historical focus of the novel is post-Emergency. This essay proposes that the novel's sprawling form is a deliberate aesthetic choice which reflects the author's engagement with the challenges of telling a national narrative from the perspective of multiple minoritarian perspectives.
\end{abstract}

Keywords: Arundhati Roy, Dalit, Hijra, Kashmir, Ministry of Utmost Happiness, Postcolonial India

\section{RESUMEN}

Publicada 20 años despuñes de su acalamada The God of Small Things, la segunda novela de Arundhati Roy, The Ministry of Utmost Happiness persigue articular la historia de India poscolonial desde el punto de vista de personajes marginales. La hijra Anjum, el intocable Saddam Hussain, y la joven disidente Tilottama destacan en esta narración polifónica, que muestra el estado laico indio como un proyecto fracasado. Aunque la historia de Anjum comienza con la Partición y sus consecuencias en la población musulmana de Delhi, la novela se centra en los ańos posteriores al período de Emergencia Nacional. Este artículo estudia la técnica narrativa polifónica como una apuesta estética de la autora para mostrar la dificultad que entrańa explicar el relato nacional desde la perspectiva de las minorías.

Palabras Clave: Arundhati Roy, Cachemira, Dalit, India postcolonial, Hijra, Ministry of Utmost Happiness. 
Published nearly 20 years after the award- winning debut novel, The God of Small Things, Roy's The Ministry of Utmost Happiness (MUOH) has been a muchanticipated novel. Unlike the first novel which had critiqued caste and gender politics in a globalizing India by focusing on a family's tragedy and pain through the coming of age story of twins, Estha and Rahel, $M U O H$, seeks to articulate a postcolonial nation's history from the perspective of the marginalized. Anjum, a hijra, and Saddam Hussain, a Dalit, and Tilottama, a maverick young woman are the main characters in this sprawling narrative and their tales intertwine to capture the failure of the secular democratic nation state. Although Anjum's family history begins with the Partition and its impact on Muslims in Delhi, the prime historical focus of the novel is post-Emergency. Roy writes of Dalit lynchings, the pogrom against Sikhs in 1984, the rise of Hindu fundamentalism and the communal riots in Gujarat, the impact of the army occupation and jihadi movements on Kashmir, and the growth of resistance movements against the government. The novel, thus, raises questions about India's democracy and the plight of minorities within this regime particularly in the last four decades.

In locating Anjum's family history in the Partition, this novel explores what many Partition scholars recognize as the continuing impact of the decolonization of the subcontinent in 1947 and the subsequent formation of two (and later three) new nations. As Ayesha Jalal has noted Partition marks a "defining moment that is neither beginning nor end" (1). Vazira Zamindar terms this "the Long Partition" and recognizes that Partition needs to be understood beyond the events of 1947. Zamindar notes that we must "stretch our understanding of 'Partition violence' to include the bureaucratic violence of drawing political boundaries and nationalizing identities that became, in some lives, interminable" (2). Partition scholars recognize that the events of 1947 transformed diverse ethnic identities and lived experiences of people and consolidated them into monolithic narratives of "Hindus," "Muslims," and "Sikhs." Urvashi Butalia, Gyan Pandey, Kavita Daiya among others have noted that the violence and upheaval of Partition also created discourses of citizenship and belonging on the subcontinent. Daiya writes "The Partition constitutes a field of transformation and a discourse that became the condition of possibility for the gendered ethnicization of citizenship and belonging in postcolonial South Asia" (5). In a similar vein, Roy's novel traces how the vectors of caste, gender, sexuality, and region intersect with Partition derived Hindu-Muslim-Sikh monolithic identities of citizenship, belonging, vulnerability, and precarity in postcolonial and post-Emergency India. Early in the novel when tracing Anjum's family history, Roy describes Partition as, "God's carotid burst open on the new border between India and Pakistan and a million people died of hatred" (17). When Anjum (born Aftab) meets Nimmo Gorakhpuri, another hijra, in the walled city of old Delhi, she tells him that the hijra home, the Khwabgah that Anjum wants to be a part of, is all "sham and fakery" (27). Nimmo continues,

No one's happy here... what are the things...normal people get unhappy about? ... Price-rise, children's school-admissions, husbands' beatings, wives' cheatings, Hindu-Muslim riots, Indo-Pak war--outside things settle down eventually. But for 
us the price-rise and school-admissions and beating-husbands and cheating-wives are all inside us. The war is inside us. Indo-Pak is inside us. It will never settle down. It can't. (27).

Thus, Roy deftly expands the discourse of Partition beyond Hindu-MuslimSikh to include the gendered body. In choosing a Dalit man, a Malayalee Christian woman, a Kashmiri man, and a hijra as her narrative focal points, Roy expands the idea of minoritization in India beyond the Partition binary of Hindu- Muslim/IndoPak. Whereas Anjum's experience in the Gujarat riots and the Kashmir question can be directly tied to the Long Partition, $M O U H$ also insists on recognizing caste, gender, and sexuality as complicating mainstream narratives of Hindu/Muslim, patriot/jihadi that permeate political discourses in the public sphere.

Roy's sprawling narrative has confounded her reviewers, many of whom seem to have expected something similar to The God of Small Things with its tightly woven plot, the acerbic political commentary, brilliant word play, and tragic characters. While some critique its sprawling form, others are challenged by its politics. Michiko Kakutani writes in The New York Times that the new novel has "moments of ...heartfelt sympathy, but it is less focused on the personal and the private than on the 'vast, violent, circling, driving, ridiculous, insane, unfeasible, public turmoil of a nation." Kakutani laments the structure of the novel which she argues "bogs down, badly, in the middle" (Kakutani 2017). Reviewing the novel in The Hindu, South Asian writer and critic Tabish Khair, guardedly praises $M U O H$ for its narrative style because it is a political novel in the same way V.S.Naipaul's novels are although the writers have radically opposed political perspectives. Khair celebrates the novel for taking a political stand and thus forgives it for all the telling it does over showing in its narrative style. He ultimately praises the novel for its ability to empathise across differences which makes the novel and its writers significant in "an age of selfies" (Kahir 2017). Thus reviewers struggle between admiring the novel for its ethical and political commitment while trying to account for its sprawl. There seems to be a lingering disappointment for some reviewers about the failure of the novel to live up to its predecessor's promise in terms of form.

I suggest that the novel in its sprawling form takes on an important question for postcolonial writing-- how does one narrate a fragmenting nation? Much of postcolonial fiction grapples with the failure of the postcolonial nation state to deliver on the promises of democracy and the betrayal of the people by the anticolonial nationalists who quickly turned into postcolonial dictators. From Chinua Achebe and Ngugi wa Thiong'o to Salman Rushdie and M.G. Vassanji, postcolonial writers have grappled with this question. Rajeswari Sunder Rajan writes:

An exhaustion with nationalist sentiments was in any case to be expected as the first exaltation of freedom subsided and the postcolonial nation settled into the bad habits of nationhood. When the nation was newly decolonized and still «developing,» a member in good standing of the Third World community of nations, it could legitimately call forth high-minded patriotic commitment. But the nation that has begun to perceive itself as transforming into a military and economic superpower is a very different entity. It is now a big as well as bad nation. (205) 
In South Asian literary works, the bloody birth of India and Pakistan often mark this shift toward disillusionment with high-minded ideals of nation. In writing about the postcolonial nightmare from the perspective of multiply marginalized minorities, Roy, as a novelist, faces the challenge of telling the many stories of contemporary India in a genre, the novel, which in using protagonists and antagonists, primary and secondary plot lines will necessarily emphasize some people and their stories above others. While Salman Rushdie in Midnight's Children had confronted a similar narrative dilemma and had used magical realism and Saleem Sinai - the switched at birth boy born of Hindu working-class parents, raised by an affluent Kashmiri Muslim family, and magically able to channel multiple voices of the many midnight's children - to narrate the birth of a postcolonial nation and its subsequent crumbling, ${ }^{1}$ Roy chooses a sprawling, multi-focal narrative that is loosely tied together by a foundling. Its patchwork of perspectives, many narrative lines, myriad characters, a narrative voice with a definite political viewpoint bring to mind Roy's political writings post The God of Small Things and MOUH straddles the boundaries between fiction and polemical prose.Roy is also aware of the politics of representation--how does an influential, upper caste/class writer represent the marginalized without appropriating or romanticizing their experiences? ${ }^{2}$ This essay proposes that the novel's sprawling form is not failure of craft but a deliberate aesthetic choice which reflects the author's engagement with the challenges of telling a story of the nation from multiple minoritarian perspectives. The novel explores the process of minoritization of populations and reframes the discussion beyond the politics of Partition. It simultaneously engages with its own project of representation by critiquing the form of the novel and its ability to contain and manage these stories - what Michiko Kakutani sees as its flaw, that it is "so lacking in centripetal forces that it threatens to fly apart into pieces" is precisely its critique of the genre and readerly expectations. At a book tour talk in Seattle, WA, in June 2017, Roy was asked about how she holds herself accountable for her social position in relation to minorities, and her response was that her narrative is impelled by justice and that allows her to write about Dalits, hijras and other marginalized people. This essay will, therefore, examine the form of the novel and how Roy addresses the problem of narrating the nation in its fragments.

In an interview with Decca Aitkenhead of The Guardian, Roy remarks that "To me there is nothing higher than fiction. Nothing. It is fundamentally who I am. I am a teller of stories. For me, that's the only way I can make sense of the world, with all the dance that it involves." In that same interview, Roy also notes that "When people say this business of 'she's the voice of the voiceless', it makes

${ }^{1}$ For a deeper discussion of how Rushdie narrates the nation in Midnight's Children, see Timothy Brennan (1989), particularly the chapter "The National Longing for Form.”

2 This question has also prevailed in the discussion surrounding the depiction of Velutha in The God of Small Things. Maryam Mirza (2016) offers an excellent review of these debates and an argument about the importance of Roy's depiction of Velutha not as an eroticized male body but as a representation of how storytelling progressively produces subaltern bodies. 
me crazy,' ... 'I say, 'There's no voiceless, there's only the deliberately silenced, you know, or the purposely unheard." (Aitkenhead 2017). As a teller of stories, Roy loosely links three major storylines. The first is the story of Anjum, born Aftab, an intersexed child, who was raised male by her birth family but joins a community of hijras where her female identity is accepted. On a pilgrimage to Gujarat, Anjum and her traveling companion, an Imam, are caught up in the 2002 Godhra riots and Anjum survives because she is a hijra and people consider it inauspicious to kill a hijra. Traumatized by the experience and unable to care for her adopted daughter, Zainab, Anjum moves into an abandoned graveyard and gradually builds lodgings over the graves and assembles a rag tag bunch of people and animals who are all refugees from "Duniya," the world outside the graveyard where heteronormativity, patriarchy, caste violence, pogroms, rape, and torture dominate. In Anjum's Jannat Guest House at the graveyard, the living and the dead commune and alternate kinship networks form that include people and animals. The second narrative line is the story of Saddam Hussein, born Dayachand, a Dalit man, who had witnessed his father's lynching by caste Hindus and police because he was transporting a dead cow and was accused of having killed it. Traumatized by that violence, he adopts the name Saddam Hussein because he saw a viral video of the Iraqi dictator's execution in which the man faced his end with defiance. The Iraqi Saddam's final stance inspires Dayachand who wants to avenge his father's death. Having befriended Anjum, he moves into the graveyard with his horse and becomes part of Anjum's tribe. The third storyline focuses on S. Tillotama (Tilo), a Malayalee Christian architect from Kerala, a fictional representation of Arundhati Roy herself, who, as a college student, had had a deep friendship with three men all of whom had been in love with her. Her friend, Biplap Dasgupta nicknamed Garson Hobart in college, is an intelligence officer in Kashmir and the other two men, Naga and Musa, are a journalist and a Kashmiri nationalist respectively. Tilo's love affair with Musa draws her to Kashmir where the Indian army tortures Kashmiris seeking independence and labels them jihadis. Musa has become a freedom fighter after his wife and daughter, Miss Jabeen, are killed by the Indian army while watching a funeral parade of Kashmiri martyrs. Tilo is detained by the occupying Indian army and is being interrogated by the notorious torturer Amrik Singh when she is rescued by Dasgupta and Naga. Tilo marries Naga to avoid the Indian government forces but eventually separates from Naga and becomes the keeper of Musa's secrets. Tilo's path crosses that of Anjum and Saddam at a massive protest rally at Jantar Mantar where numerous groups from Kashmiri mothers of the disappeared to Maoist fighters and Bhopal gas tragedy victims have gathered to protest corruption and seek redress for various injustices. At this rally, an abandoned baby girl becomes the object of both Anjum and Tilo's interest and Tilo kidnaps the baby. Tilo's desire to ensure the baby's safety and Anjum's desire to raise her, brings Tilo into the Jannat Guest House graveyard community as well. What links these three stories is the assemblage of the characters at the graveyard all of whom are invested in Miss Jabeen the Second, the foundling. That loose connection between the plots challenges the reader's sense of credibility, but it is clearly a plot device intended to show that the fates of Kashmiris, Dalits, Muslims, hijras, the poor, and Maoists are all linked to how the nation is imagined 
and how that dominant national narrative sustains itself through repressing the marginalized. The marginalized are not just silenced but they are unheard and the protest at Jantar Mantar is a collective refusal to be silenced. Jannat Guest House in the graveyard is an alternative national space in which all are welcome, there are no hierarchies, no birth and blood ties between people, and no rigid identity categories, no single religion, no violence, and no boundaries between the living and the dead. The stories of each of these people - Tilo, Saddam Hussein, Anjum — and that of the myriad other characters who put in cameo appearances such Gul Kak, Azaad Bhartiya, Nimmo Gorakhpuri are those to which the novel bears witness. The novel, then, is an act of documenting these experiences.

In drawing Tilo with broad brushstrokes of her own biography —one time architect, a Syrian Christian living in Delhi, and the daughter of a feminist who established a school for girls - Roy recognizes her social position as an upper-caste, upper class intellectual telling stories of the marginalized. Tilo is a non-conformist and does not embrace mainstream notions of relationships, marriage, and motherhood. Had the Kashmir narrative been the sole focus of this novel, it would emerge as a romantic narrative of an unconventional woman and her three lovers who symbolize the different parties involved in shaping the Kashmir story - the Indian army, the journalist, and a freedom fighter. However, the Kashmir question is framed as one of the many failures of the Indian state. Kashmir is the unresolved issue from Partition and decolonization that continues to structure not just IndiaPakistan relations but also the relationship of the Indian state and army with the people of Kashmir. Additionally, as Roy writes of the 1990s and beyond in Kashmir's politics, she also recognizes the global dimensions of jihad through the story of Amrik Singh. Singh who was the torturer in chief pursuing Musa, Tilo's lover, and humiliating her in his cinema theater turned torture chamber, finds his way to the US and seeks asylum claiming to be a victim of torture and of ethnic violence as a Sikh. The asylum officer buys into his story and the family lives in California where Amrik Singh works as a truck driver. The Kashmiri freedom fighters led by Musa seek him out to avenge the many deaths of the innocent that he had caused. Eventually Singh and his family have a violent end perhaps brought about by Musa with his many passports and identity cards that facilitate his travel to the US.

Roy ties the US war on terror to the politics of Kashmir emphasizing that the Kashmiri struggle is no longer a subcontinental issue but a global one where the Indian occupation is bolstered by the American war on terror. Amrik Singh's manipulation of the Sikh experience of 1984 with his own intimate knowledge of torture in Kashmir to achieve asylum in the United States underscores that subaltern identities are not fixed. To be Sikh is to be both vulnerable to ethnic cleansing as in 1984 and also to be an agent of the Indian army perpetrating violence on others, particularly Kashmiri Muslims. Amrik Singh's wife, who was a victim of domestic violence, convinces the asylum officer that her fears were from the political situation in Kashmir that put her life at risk. Her role in the asylum process marks both her position as active agent in rewriting the Kashmir narrative while simultaneously being victim of the chief torturer. Through Tilo Roy unpacks the many complex and often contradictory views promulgated about Kashmir, and 
presents her character as a moral compass for the reader. Tilo documents what she sees in Kashmir, helps Azaad Bhartiya publish his newsletter about governmental atrocities, and befriends people irrespective of their caste, religion, class, or gender identity. In the alternative national space, the Jannat guest house, she becomes ustaniji (teacher) who equips young people with skills to continue the struggle. She is an ally of the different groups - Kashmiri freedom fighters, hijras, Dalits, Maoists - and has risked her own life in the pursuit of justice. Through Tilo, Roy articulates the need for solidarity amongst different marginalized groups. By not tying up their stories in a novel that smoothes over inconsistencies and incongruities through slick plot devices, she suggests that the genre must incorporate fable, magical realism, testimonio, reportage and abandon the compulsion to tell stories with beginnings, middles, and ends where all ends well and the world is a better place.

Roy's narrative is also punctuated by self-conscious moments where different methods of truth telling and story -telling are explored. Very early in the novel, Anjum is telling Zainab, her young daughter, a bedtime story based on her life. To the child, Anjum speaks of returning from a party with other hijras and walking over the Defence colony flyover and needing to urinate and not being able to stop to answer nature's call. To Zainab, the point of the story, was scatalogical humor and Anjum's conversation with a lady on a billboard advertising Bombay Dyeing bath towels. Anjum, the narrative notes, "began to rewire a simpler, happier life for herself" to please her daughter, and "the rewriting in turn began to make Anjum a simpler, happier person" (38). The reader learns that Anjum had edited out of her story the fact that this particular flyover story had occurred in 1976 at the height of the Emergency when Sanjay Gandhi and his Youth Congress terrorized ordinary people. Anjum and her hijra colleagues had gone to a wedding party when the police arrived, arrested the hosts, and beat up the hijras and their driver. The hijras ran over the flyover to save their lives and the Flyover story retained some elements of truth including that "Anjum really did piss while she ran. There really was an advertisement for Bombay Dyeing towels on the Defence Colony flyover" (39). Through this episode, Roy highlights that stories are intentionally changed in retelling sometimes because of the audience and at other times because the teller edits out traumatic and shameful moments to become a "happier person." We, the audience of this novel, then are called upon to ponder our role as audience of difficult stories and what it means for someone to express a traumatic event. The act of listening to these stories necessarily makes the teller relive the trauma and the act of bearing witness as listener then comes with the responsibility of recording it honestly and retelling it to others responsibly.

In a later episode, Kulsoom Bi, the Ustad of Anjum's hijra gharana, regularly takes her hijras to the Sound and Light show at the Red Fort. The novel tells us that this was an old government-approved version of Indian history focused on emperors who had ruled the land for the two hundred years preceding British rule. Kulsoom was interested in the brief episode focused on Mohammad Shah Rangeela's rule and the year 1739. In the show, the invading armies of Nadir Shah approach Delhi and the unperturbed Emperor orders music to play on. Ustad Kulsoom Bi waited for the moment when the show focused on the zenana and amidst the tinkle of anklets 
"suddenly, amidst the soft, happy, lady-sounds would come the clearly audible, deep, distinct, rasping coquettish giggle of a court eunuch" (55). For Kulsoom Bi, this was a moment of triumph because "To be present in history, even as nothing more than a chuckle, was a universe away from being absent from it, from being written out of it altogether" (55). At the end of the novel, as the Hindutva government of "Gujarat ka Lalla" (Narendra Modi) sweeps into power, the Sound and Light show at the Red Fort is subjected to revision and "Soon centuries of Muslim rule would be stripped of poetry, music and architecture and collapsed into the sound of the clash of swords and a bloodcurdling war cry that lasted only a little longer than the husky giggle that Ustad Kulsoom Bi had hung her hopes on. The remaining time would be taken up by the story of Hindu glory. As always, history would be a revelation of the future as much as it was a study of the past." (407). The tourist focused and government derived history of the Sound and Light show is an example of how the nation presents its history to its citizen tourists as well as to its foreign visitors. Early in the novel, the show becomes an example of how an elderly hijra seeks self representation, even a passing one, in such a show to validate her existence. In the rewriting of the show by the Hindutva government not only does Roy demonstrate ideological appropriations of history but sets her own project in opposition to the dominant historical narrative embraced by the Hindutva regime. Not only is this novel a critique of Hindu fundamentalist hegemony, it also seeks to write history from the margins. Hijras are not just a passing, disembodied laughter but a strong narrative focal point. Muslims are represented not through the binary of patrons of high culture/marauding invaders but also as transgendered bodies.

Through Tilo Roy explores alternative ways of writing history: "Tilo had been a weird, part-time stenographer to a full-time military occupation" (274). During her trips to Kashmir she had collected an assortment of photographs, story fragments, observations and they "appeared to have no purpose." (274). She assembled an "archive of recoveries, not from a flood, but from another kind of disaster" (274) that had become dangerous. One of her notebooks titled The Reader's Digest Book of English Grammar and Comprehension for Very Young Children comes back to her with Musa's papers. Mimicking a children's textbook, the notebook contains various vignettes of bloodshed, violence, and oddities. From the death of innocent civilians to the conundrum of cattle crossing the Line of Control from India to Pakistan, these vignettes are followed by seemingly innocuous questions such as those found in textbooks for reading comprehension. The notebook vignettes run several pages and interrupt the main story and the reader joins Tilo for a length of time reviewing her notebook. Tilo had grappled with how to tell the story of Kashmir and in the satire of the textbook genre, Roy critiques the educational system for covering up history because educational systems are geared to produce adults who subscribe to the nation's ideology. Unlike Anjum who had edited her story to make it tolerable to a young listener and to manage her own memories of the trauma, the state produces history books to present only its version of the events. As with the Sound and Light show, these state versions change over time when governments and ideologies shift as well. 
Roy's project cannot be wholly represented by Anjum's approach to history nor to Tilo's gathering of scraps of information with no purpose and rendering them into a satirical and incomplete textbook for children. At the end of the novel, Tilo writes a poem she reads to Musa on his last visit to her at the Jannat guest house:

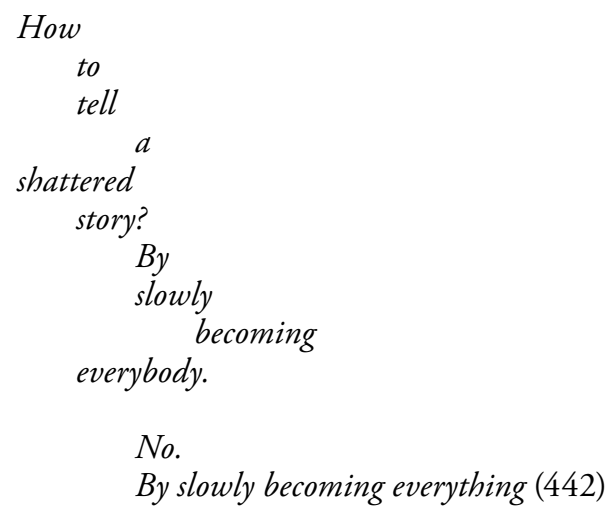

This brief poem encompasses Roy's underlying premise of this novel. She is writing the fragmented and broken narrative of a nation. There are many stories that must be recovered and that need a "stenographer." Such stories can be told only when the teller becomes everyone and everything. What does such becoming entail? Is it the ability to imaginatively enter the consciousness of a person or thing vastly different from you? Is it embodying everyone and everything? Can an uppercaste woman become a Dalit and tell his story? Can a cisgendered Syrian Christian woman embody a transgender Muslim? Roy's response is to write a novel that is very loosely held together by an assortment of characters and where the last words belong to a dung beetle who lay on his back "to save the world in case the heavens fell" and who celebrated the foundling girl, Miss Udaya Jabeen, born of the gang rape of a Maoist activist, kidnapped by a woman who did want to be a mother, and raised by a hijra who passionately wanted to be one (441).

Miss Udaya Jabeen, the foundling from Jantar Mantar, becomes another element in the narrative that brings the different plot lines together. The Jannat Guest house denizens learn about her history after a letter arrives for them through Azaad Bhartiya. Her mother had been a Maoist fighting for land rights who had been gang raped by police. She named her baby, born of that rape, Udaya or "Dawn." Clearly, the baby is intended to be a symbol of the nascent alternative to the degenerating and fragmented postcolonial state. She is also named Miss Jabeen the Second by Tilo after Musa's young daughter who had died in her mother's arms when a stray bullet killed them both. Miss Jabeen had always demanded "Akh daleela wann"(Tell me a story) of her father (322), and he had engraved that rhyme on her gravestone. Udaya Jabeen represents that never-ending story of the next generation who will craft their own narratives of citizenship and belonging.

In The Ministry of Utmost Happiness, Roy radically questions the form of the novel derived from Western forms and adapted and developed by Indian writers. 
She signals through her hybrid and sprawling form that fragmenting nations need narrative forms that offer diverse voices a place of expression. For her, the Indian English novel of the new millennium needs a moral compass and a relentless pursuit of justice, and The Ministry of Utmost Happiness is her exploration of both justice and genre.

Reviews sent to author: 30 November 2017

Revised paper accepted for publication: 2 March 2018 


\section{REFERENCES}

Aitkenhead, Decca. “'Fiction Takes Its Time': Arundhati Roy on Why it Took 20 Years to Write Her Second Novel.” The Guardian, May 27, 2017. https://www.theguardian.com/books/2017/ may/27/arundhati-roy-fiction-takes-time-second-novel-ministry-utmost-happiness. Accessed December 1, 2017.

Brennan, Timothy. Salman Rushdie and the Third World: Myths of the Nation. St. Martin's Press, 1989.

Darya, Kavita. Violent Belongings:Partition, Gender, and National Culture in Postcolonial India. New Yoda, 2008.

Jalal, Ayesha. The Pity of Partition: Manto's Life, Times, and Work Across the India-Pakistan Divide. Princeton University Press, 2013.

Kakutani, Michiko. “Arundhati Roy's Long-Awaited Novel is an Ambitious Look at Turmoil in India" New York Times. June 5, 2017. https://www.nytimes.com/2017/06/05/books/reviewarundhati-roy-ministry-of-utmost-happiness.html?_r=1. Accessed December 1, 2017.

Khair, Tabish. "What Magic Reveals, What Magic Hides." The Hindu. June 10, 2017. http:// www.thehindu.com/books/arundhati-roy-the-ministry-of-ttmost-happiness-review/article18910916.ece. Accessed December 2, 2017.

Mirza, Maryam. "Intimacy Across Caste and Class Boundaries in Arundhati Roy's The God of Small Things." Dalit Literatures in India. Joshil K. Abraham and Judith Misrahi-Barak eds., Routledge, 2016. 263-276.

Roy, Arundhati. The God of Small Things. Harper Collins, 1997.

The Ministry of Utmost Happiness. New York: Knopf, 2017.

Rushdie, Salman. Midnight's Children. Knopf, 1980.

Sunder Rajan, Rajeswari. "After 'Midnight's Children': Some Notes on the New Indian Novel in English” Social Research 78.1 (Spring 2011): 203-230.

Zamindar, Vazira and Fazila Yacoobali. The Long Partition and the Making of Modern South Asia. Columbia University Press, 2007. 
